\title{
UK gene-release suspended after protests
}

London. Researchers planning to release a genetically modified virus in a field in Oxfordshire, England, have suspended their experiment for 14 days following protests from scientists, local residents and environmental and conservation groups.

The research was due to begin last week. It involves spraying caterpillar-infested cabbages with an insecticidal baculovirus (Autographa californica NPV) carrying a scorpion toxin gene, and is being led by David Bishop of the Natural Environment Research Council (NERC)'s Institute of Virology and Environmental Microbiology in Oxford. Bishop maintains that the risks and environmental impact are "minimal or nil". He points out that the work is a repeat of a similar experiment at the same site last year, and that it has already been given full safety clearance by the Department of the Environment (DoE).

But opponents disagree with Bishop that the safety of the experiment has been adequately examined. They suggest, for example, that potential dangers arising from the organisms's genetic stability and host range (see Nature 353, 394; 1991), have been underestimated. They are also angry that their objections to the release seem to have been ignored by the department, and point out that they were not even given enough time to register their objections.

George Smith, a materials scientist at the University of Oxford who lives near the release site, has called for a "full, in-depth, wide-ranging public inquiry" into procedures for granting consent to releases of genetically modified organisms. He argues that current arrangements for public consul-

\section{French agency opens laboratory in Japan}

Paris. France's Centre National de la Recherche Scientifique (CNRS) has opened its first laboratory in Japan. CNRS says that the Laboratory for Integrated Micromechatronic Systems (LIMMS), to based at the University of Tokyo, will help to balance the current trend where more Japanese researchers work in France than the other way round. By associating the LIMMS with three existing laboratories in France, CNRS also hopes to improve the reintegration of French researchers returning from Japan.

LIMMS will not have its own buildings, except for an office for the director, and the researchers will instead be spread out in Japanese laboratories to "avoid risk of isolation". The laboratory is seeking partners from French public and industrial sectors. CNRS opened a permanent office in Tokyo in 1992. It also offers courses in Japanese to its researchers.

D. B. tation "are inadequate to deal with matters of such widespread concern and importance".

But the DoE points out that neither it, nor its Advisory Committee on Release to the Environment (ACRE), has a statutory obligation to consult the public about such releases. The only obligation on researchers is that they place an advertisement of their proposed work in a local newspaper.

The NERC team did this. It also invited the public to seek additional information from - and to send comments to - the DoE. But the trial was given the go-ahead before the department sent Smith the documents he required to carry out his own review of the proposal.

Smith, whose protests are being backed by Friends of the Earth, complains that he was given no indication of the decisionmaking time-scale, and was never informed by the department that the test had been

approved, even though he had submitted a formal objection a day after the advertisement appeared.

Earlier last week, lawyers acting for the protesters lodged a complaint with John Gummer, the Environment Secretary, claiming that the department had created a "legitimate expectation that the objections of members of the public would be taken into account" and had failed to fulfil this commitment. They also draw attention to discrepancies between the advertisement and the public register about the sites's exact location.

But a spokesman for the department says that it has "complied fully" with legislation. Although a meeting was held on 24 May at which the department discussed the complaints with its advisers, officials insist that this was a routine event, and was not prompted by the Oxford situation.

Peter Tallack

\section{Nature, not levees, blamed for flood}

Washington. The Great Mississippi Flood of 1993 was a rare natural event whose impact was not significantly worsened by existing river management policies, according to a White House task force that had been charged with framing a policy response to the flood.

General Gerald Galloway, the chairman of the task force and a US Army engineer, told a Senate hearing last week that neither the loss of natural wetlands to farmland in the Mississippi flood plain nor the use of man-made levees to constrain the river banks had contributed significantly to the severity of the flood.

Nonetheless, a draft version of the task force's report says that the flood should "serve as a catalyst" for change, and proposes action to encourage a better balance between levees and other, non-structural approaches to the management of flood plains.

The report recommends new legislation to establish a "national paradigm for floodplain management", coordinating federal, state and local action, and giving clear responsibility for leadership to state governments.

It also advocates the re-establishment of interstate river basin commissions on the Upper Mississippi, the Missouri and elsewhere, and the use of the Upper Mississippi as a cross-agency ecosystem management demonstration project.

Members of the Senate Environment and Public Works Committee, chaired by Max Baucus (Montana, Democrat), said that they welcomed the report. The committee is likely to support floodplain legislation which, Baucus hopes, will revise the mandate of the

\section{US Army Corps of Engineers.}

American Rivers, an environmental group opposed to levees, says the report shows that "this 200-year-old experiment by the Corps of Engineers has failed". But the draft report says that levees prevented $\$ 19$ billion of damage on top of the estimated \$12-\$16 billion flood damage.

John Zirschky, acting assistant army secretary in charge of the Corps, says that the Corps will welcome a change in mandate

\section{IMAGE UNAVAILABLE FOR COPYRIGHT REASONS}

ast year's flood: "a catalyst".

enabling it to take into account non-economic factors (such as environmental conservation) in its work. Galloway says the Corps "needs funding to use some of the techniques it has known about for years".

There remains a sharp disparity of view on how quickly levee repair work is actually proceeding on the Mississippi (see Nature 364, 747; 1993). Senator Chris Bond (Republican, Missouri) says that "unconscionable" bureaucratic delays meant that "only 19 out of 500 levees were fixed by December". But Zirschky says that repairs to 71 per cent of damaged levees are complete or under way.

Colin Macilwain 